\title{
Withdrawal of Sibutramine for Weight Loss: Where Does This Leave Clinicians?
}

\author{
Sébastien Czernichow ${ }^{\mathrm{a}, \mathrm{b}}$ G. David Batty ${ }^{\mathrm{c}, \mathrm{d}^{*}}$ \\ ${ }^{a}$ Nutritional Epidemiology Research Unit (UMR INSERM U557, INRA, CNAM, UP13), \\ ${ }^{\mathrm{b}}$ Department of Public Health, Avicenne Hospital, Bobigny, France; University of Paris 13, Bobigny, France \\ ${ }^{\mathrm{C}}$ Medical Research Council Social and Public Health Sciences Unit, Glasgow, \\ ${ }^{\mathrm{d}}$ Department of Epidemiology and Public Health, University College London, London, UK
}

As has been well documented, the disorders of overweight and obesity currently affect more than 1.1 billion people worldwide [1]. In several developed countries more than two thirds of adults are overweight, as defined by a BMI in excess of $25 \mathrm{~kg} / \mathrm{m}^{2}$. Recent data from selected European countries and in the USA may signal a plateau in the prevalence of overweight or obesity, or even a decrease [2-5] - observations that warrant further testing in other populations as they could have very real consequences for preventative and curative health planning [6]. This notwithstanding, health practitioners still have to legislate for a considerable health burden associated with the present cohort of obese or extremely obese individuals. Thus, the present challenge is to implement preventative strategies at a population level, but also, crucially, to treat those who need to lose weight using behavioural modification, with or without pharmacological intervention or batriatric surgery.

The cornerstone of non-pharmacological weight loss interventions is modification in energy intake and expenditure; however, the evidence for this approach is somewhat disappointing. A recent overview of 43 trials comprising 3,476 adult participants concluded that, when compared with no treatment, exercise resulted in some weight loss. In conjunction with dietary change, a greater weight reduction was apparent than for diet alone [7] although, again, the impact was small (weighted mean difference: $-1.0 \mathrm{~kg}$; $95 \%$ confidence interval (CI): -1.3 to $-0.7 \mathrm{~kg}$ ). Until quite recently, the most widely used pharmacological alternatives, or adjuncts to lifestyle change, were orlistat (a gastrointestinal lipase inhibitor) [8], rimonabant (an endocanabinoid receptor inhibitor) [9], and sibutramine (a norepine-

*G. David Batty is a Welcome Trust Research Fellow phrine and serotonin re-uptake inhibitor) [10]. Randomised trials have demonstrated that, relative to placebo, these drugs are associated with a marked weight loss in both adults and adolescents in the range of 3 to $5 \mathrm{~kg}$ [11-13].

Amidst some reports that sibutramine was having unfavourable effects on blood pressure and resting heart rate, the manufacturer, Abbott Laboratories, commenced SCOUT (Sibutramine Cardiovascular Outcome Trial) in 9,800 overweight or obese persons who were also at high cardiovascular disease (CVD) risk [14-16]. Although the final results are not yet published, the European Medicines Agency (EMA) was informed by the study's Data Safety Monitoring Board of the preliminary results. The evidence was that, following 6-year follow-up of trial participants, the rate of serious CVD events was higher in trial members taking sibutramine compared to those treated with the placebo. Accordingly, following review, on January 21, 2010 the EMA reasoned that the risks of sibutramine outweighed the benefits (www.ema.europa.eu/ pdfs/human/referral/sibutramine/3940810en.pdf) and recommended the removal of sibutramine from all markets in the European Union.

In detail, the EMA chose to suspend the drug because of i) the potential for raised CVD risk in obese patients, ii) a marginal weight loss compared to placebo, and iii) a lack of data on weight loss maintenance after drug cessation. This decision is somewhat debatable. Before the early results from SCOUT emerged, as described, it was already known that sibutramine had an unfavourable influence on selected CVD risk factors. Hence, while still on the market, sibutramine was contra-indicated in patients with existing CVD. The weight loss of $2-4 \mathrm{~kg}$ obtained with using sibutramine is similar to that seen with drugs still available (orlistat). Finally, as for other weight loss drugs, cessation of treatment is followed by weight regain.

\begin{tabular}{ll}
\hline KARGER & ( ) 2010 S. Karger GmbH, Freiburg \\
Fax +497614520714 & $\begin{array}{l}\text { Accessible online at: } \\
\text { www.karger.com/ofa } \\
\text { www.karger.com }\end{array}$ \\
\end{tabular}


So where does this leave clinicians? In addition to the usual lifestyle changes which, as described, seem to produce rather modest effects on weight loss, it may be that this leaves us with one pharmacological option: orlistat [17]. Among the latest drug developments are glucagon-like peptide-1 (GLP-1) agonists which are produced naturally by the gastrointestinal tract and have been implicated in the regulation of food intake. Originally developed to treat type-2 diabetes, the efficacy of liraglutide for weight management was tested in a double blind, 20-week randomised, controlled trial versus placebo or open-label orlistat [18]. The resultant weight loss ranged from 4.8 to $7 \mathrm{~kg}$ with increasing liraglutide dose, ver- sus 2.8 and $4.1 \mathrm{~kg}$ in the placebo and orlistat groups, respectively. Compared to placebo, patients with liraglutide had more nausea and vomiting episodes, but these adverse effects appeared to be transient and generally did not lead to discontinuation of treatment.

In conclusion, early results for liraglutide are promising and, for now at least, it appears to offer no worrying impact on CVD risk factors. Before further data on the long-term effects of this drug on CVD risk factors and morbidity become available - crucially given the afore described problems of other medication - the use of liraglutide in obese patients with type 2 diabetes seems a reasonable option.

\section{References}

1 Haslam DW, James WP: Obesity. Lancet 2005;366 (9492):1197-1209.

2 Ogden CL, Carroll MD, Curtin LR, McDowell MA, Tabak CJ, Flegal KM: Prevalence of overweight and obesity in the United States, 1999-2004. JAMA 2006;295(13):1549-1555.

$\checkmark 3$ Czernichow S, Vergnaud AC, Maillard-Teyssier L, Peneau S, Bertrais S, Mejean C, et al: Trends in the prevalence of obesity in employed adults in central-western France: a population-based study, 1995-2005. Prev Med 2009;48(3):262-266.

4 Charafeddine R, Van Oyen H, Demarest S: Trends in social inequalities in obesity: Belgium, 1997 to 2004. Prev Med 2009;48(1):54-58.

$\checkmark 5$ Peneau S, Salanave B, Maillard-Teyssier L, Rolland-Cachera MF, Vergnaud AC, Mejean C, et al: Prevalence of overweight in 6- to 15-year-old children in central/western France from 1996 to 2006: trends toward stabilization. Int J Obes (Lond) 2009; 33(4):401-407.

6 Hercberg S, Chat-Yung S, Chauliac M: The French National Nutrition and Health Program: 2001 2006- 2010. Int J Public Health 2008;53:68-77.

7 Shaw K, Gennat H, O'Rourke P, Del Mar C: Exercise for overweight or obesity. Cochrane Database Syst Rev 2006;(4):CD003817.

$>8$ Torgerson JS, Hauptman J, Boldrin MN, Sjostrom $\mathrm{L}$ : XENical in the prevention of diabetes in obese subjects (XENDOS) study: a randomized study of orlistat as an adjunct to lifestyle changes for the prevention of type 2 diabetes in obese patients. Diabetes Care 2004;27(1):155-161.
9 Van Gaal LF, Rissanen AM, Scheen AJ, Ziegler O, Rössner S: Effects of the cannabinoid-1 receptor blocker rimonabant on weight reduction and cardiovascular risk factors in overweight patients: 1-year experience from the RIO-Europe study. Lancet 2005;365(9468):1389-1397.

10 James WP, Astrup A, Finer N, Hilsted J, Kopelman P, Rössner S, et al: Effect of sibutramine on weight maintenance after weight loss: a randomised trial. STORM Study Group. Sibutramine Trial of Obesity Reduction and Maintenance. Lancet 2000;356(9248):2119-2125.

11 Rucker D, Padwal R, Li SK, Curioni C, Lau DC: Long term pharmacotherapy for obesity and overweight: updated meta-analysis. BMJ 2007;335 (7631):1194-1199.

12 Lloret-Linares C, Greenfield JR, Czernichow S: Effect of weight-reducing agents on glycaemic parameters and progression to type 2 diabetes: a review. Diabet Med 2008;25(10):1142-1150.

13 Czernichow S, Lee CM, Barzi F, Greenfield JR, Baur LA, Chalmers J, et al: Efficacy of weight loss drugs on obesity and cardiovascular risk factors in obese adolescents: a meta-analysis of randomized controlled trials. Obes Rev 2010;11(2):150-158.
14 Caterson I, Coutinho W, Finer N, Van Gaal L, Maggioni A, Torp-Pedersen C, et al: Early response to sibutramine in patients not meeting current label criteria: preliminary analysis of SCOUT lead-in period. Obesity (Silver Spring) 2010;18(5): 987-994.

15 Torp-Pedersen C, Caterson I, Coutinho W, Finer N, Van Gaal L, Maggioni A, et al: Cardiovascular responses to weight management and sibutramine in high-risk subjects: an analysis from the SCOUT trial. Eur Heart J 2007;28(23):2915-2923.

16 Van Gaal LF, Caterson ID, Coutinho W, Finer N, Maggioni AP, Sharma AM, et al: Weight and blood pressure response to weight management and sibutramine in diabetic and non-diabetic high-risk patients: an analysis from the 6-week lead-in period of the sibutramine cardiovascular outcomes (SCOUT) trial. Diabetes Obes Metab 2010;12(1):26-34.

17 Williams G: Withdrawal of sibutramine in Europe. BMJ 2010;340:c824.

18 Astrup A, Rössner S, Van Gaal L, Rissanen A, Niskanen L, Al Hakim M, et al: Effects of liraglutide in the treatment of obesity: a randomised, double-blind, placebo-controlled study. Lancet 2009; 374(9701):1606-1616. 